Brit. J. vener. Dis. (1966), 42, 269.

\title{
CONTROLLED STUDY OF THE PREVALENCE OF T STRAIN MYCOPLASMATA IN MALES WITH NON-GONOCOCCAL URETHRITIS*
}

\author{
BY \\ H. R. INGHAM, W. V. MACFARLANE, J. H. HALE, \\ J. B. SELKON, AND A. A. CODD \\ From the Regional Public Health Laboratory and the \\ Newcastle General Hospital, Newcastle upon Tyne
}

Shepard (1956) and Shepard, Alexander, Lunceford, and Campbell (1964) reported the isolation from men with non-gonococcal urethritis of a species of mycoplasma which formed very small colonies on culture. The organisms were isolated from 86 per cent. of 79 men in the first study and from 51 per cent. of 64 men in the second. This organism was subsequently called $\mathrm{T}$ strain mycoplasma.

Ford, Rasmussen, and Minken (1962) and Ford and Duvernet (1963) found that whereas $T$ strain mycoplasmata were isolated from 60 to 79 per cent. of patients with non-gonococcal urethritis, they were found in only 21 to 48 per cent. of normal males. Similar findings were reported by Csonka, Williams, and Corse (1966).

These findings suggested that $\mathrm{T}$ strain mycoplasma could be an aetiological agent in non-gonococcal urethritis. However, these organisms were also isolated from control groups of patients and the proportions of controls who have yielded this organism have varied considerably. This variation was possibly due to differences in the age and social characteristics of the control groups studied and to difference in the methods used for collecting specimens from the different groups.

The present study was undertaken in order to compare the prevalence of $\mathrm{T}$ strain mycoplasma in patients suffering from non-gonococcal urethritis and in comparable groups of males not suffering from this disease.

\section{Patients and Methods}

Three groups of males were examined. All were over 16 years of age and none gave a history of previous urethritis or prostatitis.

(1) Patients with Non-gonococcal Urethritis (45).The diagnosis of non-gonococcal urethritis was made on the basis of a mucopurulent urethral discharge which on

\footnotetext{
* Received for publication June 6, 1966
}

microscopic examination did not reveal gonococci, and failure to demonstrate Trichomonas vaginalis in the urine. The average age of the patients in this group was 25 years.

(2) Normal Controls (54).- These were men seeking reassurance that they had not contracted venereal disease as the result of sexual exposure. Their average age was 29 years.

(3) Patients with Gonorrhoea (36).--Men presenting with gonorrhoea were included as an additional control group because of the possibility that the presence of $T$ strain mycoplasmata might simply represent an index of sexual activity. Their average age was 29 years.

Collection of Specimens.-These were obtained from all patients by inserting a rigid $4 \mathrm{~mm}$. diameter wire loop 2 inches into the urethra and exerting gentle pressure on the urethral mucosa on withdrawal. The specimens so obtained were inoculated immediately on to a solid medium and into broth.

Cultural Methods.-PPLO agar (Difco) supplemented with 10 per cent. horse serum (Burroughs Wellcome No. 3 ) and 10 per cent. fresh yeast extract and containing 1,000 units penicillin per ml. was used to prepare the solid medium. The liquid medium consisted of Oxoid sensitivity broth to which the same supplements were added. The broth cultures were incubated at $37^{\circ} \mathrm{C}$. in an atmosphere of 80 per cent. nitrogen and 20 per cent. $\mathrm{CO}_{2}$ for 16 hours, and were then subcultured on to the solid medium. The latter was incubated under identical conditions for 4 days.

Any small mycoplasma colonies that appeared were studied by the staining procedure of Dienes (Madoff, 1960), and permanent preparations were made by fixing small blocks of agar on coverslips with Bouin's fixative and staining with $1 / 50$ Giemsa for 2 hours.

T strain mycoplasma were differentiated from the larger mycoplasma species by their small size, refractile appearance, and failure to increase in size after $48 \mathrm{hrs}$ ' incubation.

\section{Results}

T strain mycoplasmata were isolated from 66 per cent. of the 45 patients with non-gonococcal 
urethritis, from 61 per cent. of the 36 patients suffering from gonorrhoea, and from 48 per cent. of the 54 normal controls (Table). The difference between the patients with non-gonococcal urethritis and the normal controls fails to attain statistical significance $(0.1<\mathrm{P}>0.05)$. There was also no significant difference between these three groups of patients in the proportions who yielded $T$ strains on direct plating of the specimens, i.e. without initial enrichment in broth. The normal controls were followed up for 13 weeks from the date of their exposure. None of them developed non-gonococcal urethritis during this period.

TABLE

ISOLATION OF T STRAIN MYCOPLASMA FROM THE MALE GENITAL TRACT

\begin{tabular}{c|c|c|c|c|c}
\hline \multirow{2}{*}{$\begin{array}{c}\text { Group of } \\
\text { Patients }\end{array}$} & $\begin{array}{c}\text { Total } \\
\text { Patients } \\
\text { Examined }\end{array}$ & \multicolumn{2}{|c|}{ T Strain Isolations } & \multicolumn{2}{|c}{$\begin{array}{c}\text { Total Patients } \\
\text { Positive }\end{array}$} \\
\cline { 3 - 6 } & $\begin{array}{c}\text { Broth and } \\
\text { Plates }\end{array}$ & $\begin{array}{c}\text { Broth } \\
\text { Only }\end{array}$ & No. & $\begin{array}{c}\text { Per } \\
\text { cent. }\end{array}$ \\
\hline $\begin{array}{c}\text { (1) Non-gonococcal } \\
\text { Urethritis }\end{array}$ & 45 & 19 & 11 & 30 & 66 \\
\hline (2) Normal controls & 54 & 20 & 6 & 26 & 48 \\
\hline (3) Gonorrhoea & 36 & 15 & 7 & 22 & 61 \\
\hline
\end{tabular}

Of the 45 patients with uncomplicated non-gonococcal urethritis, 37 were treated with tetracycline $250 \mathrm{mg}$. 6-hrly for 3 days. Failure to respond to treatment with this agent was observed in four
(15 per cent.) of the 26 patients who yielded $T$ strain mycoplasmata initially and in two (18 per cent.) of the eleven who did not yield this organism.

Two morphologically distinct forms of colony were observed, one type presented the classical fried-egg appearance typical of many of the larger mycoplasmata, and the other consisted of a dense central core without peripheral extension (Figure). Both types of colony were seen in all three groups of patients, but the compact type was more commonly present. Examination of clones prepared by subculturing single colonies revealed that any one clone could give rise to both types of colony, though not usually simultaneously. Thus colony form is not a stable characteristic of these organisms and possibly depends on variation in cultural conditions.

\section{Discussion}

The difference reported in this paper between the isolation rate of $T$ strain mycoplasma in patients suffering from non-gonococcal urethritis and the control groups fails to attain statistical significance. Although in this survey the isolation rate from patients suffering from non-gonococcal urethritis was similar to that obtained in previous controlled investigations (Ford and others, 1962, 1963; Csonka and others, 1966) the percentage of control patients yielding the organism was higher. In our opinion this is probably due to the fact that, unlike the other investigators, we collected specimens by exactly 
the same techniques both in patients and controls. Moreover, the normal controls were selected in such a way that they were more likely to resemble the patients with non-gonococcal urethritis in terms of their sexual activity. It is of interest that the isolation rate of $\mathbf{T}$ strain mycoplasma in the gonorrhoea control group was 61 per cent., which is almost the same as that for patients with non-gonococcal urethritis. Thus the present study does not support the suggested aetiological role for $\mathrm{T}$ strain mycoplasma in non-gonococcal urethritis.

The high isolation rate in cases of gonorrhoea could be due to double infections. However, only those patients in whom penicillin therapy alone eliminated the gonococcus were included in the final analysis. Although this treatment would be without effect on T strains, only four of these patients developed non-gonococcal urethritis within 19 days of their first attendance. Furthermore, from two only of these were $\mathrm{T}$ strains initially isolated.

The inclusion of high concentrations of penicillin in the media, in order to prevent the growth of bacterial contaminants, raises the theoretical possibility that $\mathrm{L}$ forms may have been induced and that young $\mathrm{L}$ form colonies were mistaken for $\mathrm{T}$ strain mycoplasmata. In order to investigate this possibility, twelve $T$ strains isolated from the gonococcal control group were serially passaged in penicillin-free medium. The colonial appearance of these organisms remained unchanged during twelve consecutive passages and all strains remained oxidase-negative.

If $T$ strain mycoplasmata are aetiological agents in a proportion of cases of non-gonococcal urethritis, it should be possible to show some difference, antigenic or otherwise, between the strains isolated from patients and those from normal individuals. An alternative hypothesis is that some individuals become hypersensitive to the presence of these organisms; the possibility that non-gonococcal urethritis may be an allergic disorder has been discussed by Weston (1965). Attempts are being made in this laboratory to ascertain whether differences do in fact exist among the $\mathrm{T}$ strain mycoplasmata.

\section{Summary}

The prevalence of $T$ strain mycoplasmata was investigated in patients suffering from non-gonococcal urethritis and in two groups of male controls. $T$ strain mycoplasmata were isolated from 66 per cent. of 45 patients suffering from non-gonococcal urethritis, from 61 per cent. of 36 patients with gonorrhoea, and from 48 per cent. of 54 normal controls. These differences are not statistically significant. The possible reasons for the difference between the findings obtained in this survey and those in previous controlled investigations are discussed.

The authors are indebted to $\mathrm{Mr} \mathbf{J}$. A. Hall and $\mathrm{Mr}$ W. J. S. Smith for their able technical assistance and to $\mathrm{Mr} \mathrm{A}$. W. Whillis for the photomicrographs.

\section{REFERENCES}

Csonka, G. W., Williams, R. E. O., and Corse, Jean (1966). Lancet, 1, 1292.

Ford, D. K., Rasmussen, G., and Minken, J. (1962). Brit.J. vener. Dis., 38, 22.

- and Duvernet, M. (1963). Ibid., 39, 18.

Madoff, S. (1960). Ann. N.Y. Acad. Sci., 79, 383.

Shepard, M. C. (1956). J. Bact., 71, 362.

Alexander, C. E., Lunceford, C. D., and Campbell, P. E. (1964). J. Amer. med. Ass., 188, 729.

Weston, T. E. T. (1965). Brit. J. vener. Dis., 41, 107.

Une étude controlée de la distribution du mycoplasme de souche $T$ chez les hommes atteints d'urétrite non-blennorragique

RÉSUMÉ

La distribution du mycoplasme de souche $\mathrm{T}$ chez les patients atteints d'urétrite non-blennorragique et chez deux groupes de contrôles mâles a été étudiée. Le mycoplasme de souche $T$ a été isolé chez 66 pour cent des 45 malades atteints d'urétrite non-blennorragique, chez 61 pour cent des 36 patients atteints de la gonorrhée et chez 48 pour cent des 54 contrôles normaux. Ces différences ne sont pas significatives au point de vue statistique. Les raisons possibles pour expliquer cette différence entre les constations obtenues dans cet exposé et celles obtenues des enquêtes controlées antérieures sont discutées. 